LEMBAGA PENJAMINAN MUTU

INSTITUT HINDU DHARMA NEGERI

DENPASAR

Volume 5 Nomor 2 Agustus 2019

ISSN : 2407-912X (Cetak)

ISSN : 2548-3110 (Online)

http://ejournal.ihdn.ac.id/index.php/JPM

\title{
PERANAN TOTAL QUALITY MANAGEMENT (TQM) DI SEKOLAH DASAR
}

\author{
Oleh \\ Putu Yulia Angga Dewi ${ }^{1}$, Kadek Hengki Primayana ${ }^{2}$ \\ Sekolah Tinggi Agama Hindu Negeri Mpu Kuturan Singaraja \\ 1anggadewiyulia@gmail.com, ${ }^{2}$ hengkiprimayana@stahnmpukuturan.ac.id
}

diterima 11 Juni 2019, direvisi 19 Agustus 2019, diterbitkan 31 Agustus 2019

\begin{abstract}
Management of education by creating a conducive learning environment and successfully fulfilling commitments in fulfilling promises as educational leaders. The low quality of human resources is a fundamental problem that can hamper development and national economic development. Along with the advancement of knowledge and technology, the socio-cultural life, socioeconomy is increasingly unacceptable to space and time. In order to build the quality of Indonesian people who are able to challenge it, clearly it requires human resources that can be relied upon in the face of competition. TQM is a quality management system that is related to continuous improvement in improving the quality of education from various aspects of sustainability. Educational quality that is acceptable from customer needs and satisfaction. The application of TQM in school organizations is carried out as an effort to improve the quality of education in schools, thereby improving the quality of schools by improving the quality of education of high quality. The implementation of a management system is always disrupted by balance. Two parties who are pro and contra arise, accept TQM and reject TQM. TQM's refusal because it affects changes in management, namely changing established values. With this pillar, it is expected to be able to help schools improve their educational processes. The implementation of integrated Quality Management in schools is inseparable from the efforts of the principal to provide assistance to the school.
\end{abstract}

\section{Keywords: Total Quality Management (TQM) and Elementary School}

\section{PENDAHULUAN}

Pendidikan merupakan usaha membantu anak didik mencapai kedewasaan, diselenggarakan dalam suatu kesatuan organisasi sehingga usaha yang satu dengan lainnya saling berhubungan dan saling mengisi. Pengelolaan pendidikan dengan menciptakan lingkungan belajar yang 
kondusif serta berkelanjutan merupakan komitmen dalam pemenuhan janji sebagai pemimpin pendidikan. Pendidikan merupakan proses berkelanjutan. Pembelajaran yang efektif dan bermakna harus bersentuhan langsung dengan kehidupan siswa dilingkungannya. Kehidupan siswa dilingkungan sekolah, keluarga dan masyarakat dipengaruhi oleh faktor-faktor internal dan eksternal yang ada pada diri siswa. Faktor-faktor tersebut antara lain faktor sosial budaya, sosial ekonomi dan keadaan geografis yang ada.

Perkembangan masyarakat dunia pada umumnya dan masyarakat Indonesia pada khususnya, sekarang ini sudah memasuki masyarakat informasi yang merupakan kelanjutan dari masyarakat modern dengan ciri-cirinya yang bersifat rasional, berorientasi ke masa depan, terbuka, menghargai waktu, kreatif, mandiri dan inovatif. Sedangkan masyarakat informasi dilihat dari penguasaan terhadap teknologi informasi, mampu bersaing, serba ingin tahu, imajinatif, mampu mengu-bah tantangan manjadi peluang, dan menguasai berbagai metode dalam memecah-kan masalah.

Pada era informasi, yang sanggup bertahan hanyalah mereka yang berorientasi ke masa depan, yang mampu mengubah pengetahuan menjadi kebijakan dan mereka yang memiliki ciri-ciri sebagaimana yang dimiliki masyarakat modern seperti tersebut di atas. Dari keadaan ini, keberadaan masyarakat suatu bangsa dengan bangsa lain menjadi sangat dekat dan satu, baik dalam bidang sosial, budaya, ekonomi dan lain-lain. Dalam segi teknologi, bangsa Indonesia sedang memasuki sektor industri, bahkan para pakar menunjukkan bahwa Indonesia harus menghadapi revolusi industri dan reformasi informasi secara bersamaan. Ini berarti, disamping harus menyelesaikan krisis yang sedang dihadapi serta ketinggalan di-bidang ilmu dan teknologi yang merupakan tumpuan industri, bangsa
Indonesia juga harus secara sadar berfikir dan bertindak sesuai dengan tuntutan abad informasi, bahkan harus berusaha berperan didalam mengarahkan perkembangan masyarakat abad informasi sesuai dengan cita-cita reformasi.

Dengan kata lain Indonesia tidak bisa mewujudkan cita-cita reformasi, serta bertahan sebagai bangsa yang berdaulat dan menentukan masa depan sendiri, apabila tidak mampu menangani dan ikut menciptakan informasi, terlebih-lebih yang bersifat strategis seperti peta kekayaan alam, dan pengembangan cara kerja dibidang produksi, serta menguasai sistem pengkomunikasiannya secara tepat waktu dan tepat sasaran. Untuk kepentingan tersebut diperlukan sumber daya manusia (SDM) yang berkualitas yang memiliki kemauan dan kemampuan untuk senantiasa meningkatkan kualitas secara terus menerus dan berkesinambungan.

Rendahnya kualitas SDM merupakan masalah mendasar yang dapat menghambat pembangunan dan perkembangan ekonomi nasional. Data statistik menunjukkan bahwa tenaga kerja Indonesia masih didominasi oleh mereka yang berpendidikan Sekolah Dasar. Rendahnya tingkat pendidikan ini merupakan penghambat kemampuan dalam mempergunakan teknologi modern untuk menghasilkan produk-produk yang memiliki daya saing. Rendahnya kualitas SDM juga akan menjadi persoalan besar dalam era globalisasi, karena era globalisasi merupakan era persaingan mutu atau kualitas (Primayana, 2016). Jika bangsa Indonesia ingin berkiprah dalam arus globalisasi, maka langkah pertama yang harus dilakukan adalah menata SDM, baik dari aspek intelektual, emosional, spiritual, kreativitas, moral, maupun tanggungjawabnya (Yulia, Dewi, \& Primayana, 2019).

Pendidikan memiliki keterkaitan erat dengan globalisasi. Pendidikan tidak mungkin menasbihkan proses globalisasi 
yang akan mewujudkan masyarakat global. Dalam menuju era globalisasi, Indonesia harus melakukan reformasi dalam proses pendidikan, dengan tekanan menciptakan sistem pendidikan yang lebih komprehensif dan fleksibel, sehingga para lulusan dapat berfungsi secara efektif dalam kehidupan masyarakat global demokratis. Untuk itu, pendidikan harus dirancang sedemikian rupa yang memungkinkan para peserta didik mengembangkan potensi yang dimiliki secara alami dan kreatif dalam suasana penuh kebebasan, kebersamaan dan tanggungjawab. Di samping itu, pendidikan harus menghasilkan lulusan yang dapat memahami masyarakatnya dengan segala faktor yang dapat mendukung mencapai sukses ataupun penghalang yang menyebabkan kegagalan dalam kehidupan bermasyarakat (Primayana, 2019).

Seiring dengan majunya pengetahuan dan teknologi maka kehidupan sosial budaya, sosial ekonomi semakin tidak dapat dibatasi oleh ruang maupun waktu. Karena apapun juga kehidupan masyarakat kita tidak dapat terlepas dari kehidupan masyarakat internasional, yang menuntut adanya sumber daya manusia yang semakin tinggi. Konsep mutu (kualitas) telah menjadi suatu kenyataan dan fenomena dalam seluruh aspek dan dinamika masyarakat global memasuki persaingan pasar bebas dewasa ini. Jika sebelumnya kualitas produk dan jasa hanya menjadi target dari dunia bisnis dan industri yang bergantung pada kepuasan pelanggan atau konsumen, maka kini dunia pendidikan mulai tertantang untuk menerapkan hal yang sama dalam menghasilkan kualitas lulusan yang mampu menjawab kebutuhan pasar kerja. Bahwa organisasi pendidikan formal (sekolah dasar sampai perguruan tinggi) sebagai institusi yang bergerak di bidang pendidikan dan pengajaran kini mulai merasakan bahwa faktor mutu menjadi sangat menentukan tingkat partisipasi dan kepercayaan masyarakat terhadap suatu lembaga pendidikan (Agung, Agung, Dewi, \& Dantes, n.d.).

Kadar kualitas SDM yang terukur akan menjadi tolak ukur untuk menambal-sulam (rekonstruksi) atau bahkan mendekonstruksi pendidikan dari waktu ke waktu. Peranan guru sebagai pendidik yang andal dan berkualitas merupakan salah satu faktor yang strategis untuk mewujudkan tujuan pendidikan. Guru harus memenuhi persyaratan kualifikasi minimal (latar belakang pendidikan keguruan/umum dan memiliki akta mengajar). Setelah guru memenuhi persyaratan kualifikasi, maka guru akan dan sedang berada pada tahapan kompetensi. Namun, fenomena menunjukkan bahwa pendidik di sekolah masih banyak yang tidak memenuhi persyaratan tersebut. Hal ini mengindikasikan bahwa peningkatan mutu di sekolah dalam rangka menghasilkan peserta didik sesuai dengan yang diharapkan masih belum optimal.

Dalam hal ini Manajemen Mutu Sekolah atau Total Quality Management sangat berperan dalam penyelenggaraan pendidikan di sekolah yang diharapkan dapat memberikan perubahan yang lebih baik sesuai dengan perkembangan, tuntutan, dan dinamika masyarakat dalam menjawab permasalahan-permasalahan pengelolaan pendidikan pada tingkat sekolah. Komponen yang paling berperan dalam meningkatkan mutu ialah peran dan fungsi guru serta peran kepemimpinan kepala sekolah.

Guna membangun kualitas manusia Indonesia yang mampu menghadapi tantangan itu, jelas memerlukan human capital yang dapat diandalkan dalam menghadapi persaingan. Kualitas human capital menjadi penentu keberhasilan persaingan global (termasuk keunggulan pendidikan), dan untuk menghasilkannya diperlukan metode yang terukur dan terencana melalui pendidikan yang bermutu. Pendidikan bermutu adalah pendidikan yang 
bekerja secara terpadu, baik pada tataran kebijakan sistem nasional, institusi, manajerial, maupun tataran teknis, sehingga terdapat sinkronisasi serta sinergi di antara tataran-tataran tersebut.

Manajemen mutu menduduki posisi menentukan dalam menghadapi persaingan, pelanggan yang terus berubah, kompleksitas produk, dan tingkat harapan pelanggan yang meningkat, karena dengan mutu itulah organisasi berkompetisi serta mampu mempertahankan eksistensinya, bahkan akan terus berkembang manakala pelanggan loyal. Pendidikan yang bermutu terdiri dari adanya input pendidikan yang bermutu dengan tersedianya guru dan tenaga kependidikan yang juga bermutu. Sistem ini biasanya disebut quality learning process. Ada banyak metode untuk mencapai kualitas pendidikan semacam itu, namun metode yang paling banyak diminati adalah Total Quality Management (TQM).

TQM merupakan sistem manajemen mutu yang berkaitan dengan upaya untuk terus meningkatkan mutu pendidikan dari berbagai aspek secara berkelanjutan. Mutu pendidikan dapat diukur dari tercapainya kebutuhan dan kepuasan pelanggan. Sebagai institusi pelayanan jasa, pendidikan perlu menciptakan budaya mutu untuk memenuhi harapan pelanggan yang cenderung mengalami perubahan. TQM menekankan pada perbaikan yang berkelanjutan dan berlandaskan kepuasan pelanggan sebagai sasaran utama yang perlu diimplementasikan di berbagai lembaga pendidikan di Indonesia agar dapat menjadi unggul dan memenangkan persaingan global. Salah satu lembaga pendidikan yang menerapkan sistem ini adalah Sekolah Dasar (SD).

\section{PEMBAHASAN}

\section{a. Mutu Pendidikan}

Membicarakan tentang pengertian kualitas atau mutu dapat berbeda makna bagi setiap orang, karena mutu memiliki banyak kriteria dan sangat tergantung pada konteksnya. Dalam mendefinisikan mutu/kualitas memerlukan pandangan yang komprehensif. Dalam hal ini, ada beberapa elemen yang bisa membuat sesuatu dikatakan berkualitas. Pertama, kualitas meliputi usaha memenuhi atau melebihi harapan pelanggan. Kedua, kualitas mencakup produk, jasa, manusia, proses, dan lingkungan. Ketiga, kualitas merupakan kondisi yang selalu berubah (yang dianggap berkualitas saat ini mungkin dianggap kurang berkualitas pada saat yang lain). Keempat, kualitas merupakan suatu kondisi dinamis yang berhubungan dengan produk, jasa, manusia, proses, dan lingkungan yang memenuhi atau melebihi harapan. Jika dilihat dari segi korelasi mutu dengan pendidikan, bahwa mutu pendidikan adalah kemampuan sekolah dalam pengelolaan secara operasional dan efisien terhadap komponenkomponen yang berkaitan dengan sekolah, sehingga menghasilkan nilai tambah terhadap komponen tersebut menurut norma/standar yang berlaku. Mutu pendidikan mengacu pada masukan, proses, luaran, dan dampaknya. Mutu masukan dapat dilihat dari beberapa sisi. Pertama, kondisi baik atau tidaknya masukan sumber daya manusia, seperti kepala sekolah, guru, laboran, staf tata usaha, dan siswa. Kedua, memenuhi atau tidaknya kriteria masukan material berupa alat peraga, buku-buku, kurikulum, prasarana, sarana sekolah, dan lain-lain. Ketiga, memenuhi atau tidaknya kriteria masukan yang berupa perangkat lunak, seperti peraturan, struktur organisasi, deskripsi kerja, dan struktur organisasi. Keempat, mutu masukan yang bersifat harapan dan kebutuhan, seperti visi, motivasi, ketekunan, dan cita-cita.

Berdasarkan deskripsi dari beberapa pakar di atas dapat disimpulkan bahwa mutu pendidikan adalah derajat keunggulan dalam pengelolaan pendidikan secara efektif dan efisien untuk melahirkan keunggulan akademis dan ekstrakurikuler pada peserta 
didik yang dinyatakan lulus untuk satu jenjang pendidikan atau menyelesaikan program pembelajaran tertentu. Dilihat dari definisi ini, maka mutu pendidikan bukanlah upaya sederhana, melainkan suatu kegiatan dinamis dan penuh tantangan. Pendidikan akan terus berubah seiring dengan perubahan zaman yang melingkarinya, sebab pendidikan merupakan buah dari zaman itu sendiri. Oleh karena itu, pendidikan senantiasa memerlukan upaya perbaikan dan peningkatan mutu sejalan dengan semakin tingginya kebutuhan dan tuntunan kehidupan masyarakat. Manajemen Mutu Terpadu sangat populer di lingkungan organisasi profit, khususnya di lingkungan berbagi badan usaha/perusahaan dan industri, yang telah terbukti keberhasilannya dalam mempertahankan dan mengembangkan eksistensinya masing-masing dalam kondisi bisnis yang kompetitif. Kondisi seperti ini telah mendorong berbagai pihak untuk mempraktekannya di lingkungan organisasi nonprofit termasuk di lingkungan lembaga pendidikan. Menurut Nawari (2003) TQM adalah manejemen fungsional dengan pendekatan yang secara terus menerus difokuskan pada peningkatan kualitas, agar produknya sesuai dengan standar kualitas dari masyarakat yang dilayani dalam pelaksanaan tugas pelayanan umum (public service) dan pembangunan masyarakat (community development). Konsepnya bertolak dari manajemen sebagai proses atau rangkaian kegiatan mengintegrasikan sumber daya yang dimiliki, yang harus diintegrasi pula dengan pentahapan pelaksanaan fungsifungsi manajemen, agar terwujud kerja sebagai kegiatan memproduksi sesuai yang berkualitas. Setiap pekerjaan dalam manajemen mutu terpadu harus dilakukan melalui tahapan perencanaan, persiapan (termasuk bahan dan alat), pelaksanaan teknis dengan metode kerja/cara kerja yang efektif dan efisien, untuk menghasilkan produk berupa barang atau jasa yang bermanfaat bagi masyarakat.

Menurut Hadari Nawawi bagi organisasi pendidikan, adaptasi manajemen mutu terpadu dapat dikatakan sukses, jika menunjukkan gejala - gejala sebagai berikut:

a) Tingkat konsistensi produk dalam memberikan pelayanan umum dan pelaksanaan pembangunan untuk kepentingan peningkatan kualitas SDM terus meningkat.

b) Kekeliruan dalam bekerja yang berdampak menimbulkan ketidakpuasan dan komplain masyarakat yang dilayani semakin berkurang.

c) Disiplin waktu dan disiplin kerja semakin meningkat.

d) Inventarisasi aset organisasi semakin sempurna, terkendali dan tidak berkurang/hilang tanpa diketahui sebab - sebabnya.

e) Kontrol berlangsung efektif terutama dari atasan langsung melalui pengawasan melekat, sehingga mampu menghemat pembiayaan, mencegah penyimpangan dalam pemberian pelayanan umum dan pembangunan sesuai dengan kebutuhan masyarakat.

f) Pemborosan dana dan waktu dalam bekerja dapat dicegah.

g) Peningkatan ketrampilan dan keahlian bekerja terus dilaksanakan sehingga metode atau cara bekerja selalu mampu mengadaptasi perubahan dan perkembangan ilmu pengetahuan dan teknologi, sebagai cara bekerja yang paling efektif, efisien dan produktif, sehingga kualitas produk dan pelayanan umum terus meningkat.

\section{b. Total Quality Management (TQM)}

Sistem untuk meningkatkan mutu (quality) telah berkembang dengan cepat dalam tahun-tahun belakangan ini. Selama dua dekade terakhir, kegiatan inspeksi telah digantikan oleh kendali mutu dan kegiatan penjaminan mutu. Saat ini sebagian besar perusahaan bekerja dengan manajemen mutu 
total (TotalQuality Management atau TQM) (Dale dan Bunney, 1999: 25).Hal ini menunjukkan bahwa evolusi manajemen mutu telah memasuki suatu sistem manajemen mutu total (TQM). Pada tahap hirarki mutu ditunjukkan tahapannya sebagai berikut: (1) inspeksi, (2) kontrol mutu, (3) penjaminan mutu, dan (4) manajemen mutu total.Tahap manajemen mutu total ini menciptakan budaya mutu yang bertujuan untuk memuaskan pelanggannya (Sallis, 2002: 19-20).

Pike dan Barnes menyebut manajemen mutu total sebagai pendekatan baru dalam manajemen mutu (1994: 21).Manajemen mutu total (TQM) didefinisikan sebagai "Management approach of an organization, centred on quality, based on the participation of all its members and aiming at long-term success through customer satisfaction, and benefits to all members of the organization and to society (Bestefe, 1999: 27).Dengan demikian TQM sebagai suatu pendekatan manajemen dalam suatu organisasi yang diarahkan pada mutu dan didasarkan pada seperangkat prinsip dasar yang bertujuan untuk meningkatkan keberhasilan organisasi pada jangka panjang secara berkesinambungan melalui kepuasan pelanggan dan kemanfaatan semua anggota organisasi.

Dalam konteks pendidikan, TQM masih tergolong baru. Inisiatif pertama untuk menerapkan metode ini secara sungguhsunguh dilakukan di sekolah-sekolah Amerika dan Inggris pada awal tahun 1990an. Sallismendefinisikan konsep TQM dalam pendidikan sebagai berikut:"TQM is a philosophy of continuous improvement, which can provide any educational institution with a set of practical tools for meeting and exceeding present and future customers needs, wants, and expectations".(Sallis, 2002: 27). Definisi ini memberikan pengertian bahwa TQM sebagai sebuah filosofi tentang perbaikan secara terus menerus yang dapat memberikan seperangkat alat praktis kepada setiap institusi pendidikan dalam memenuhi kebutuhan, keinginan, dan harapan para pelanggannya, saat ini dan untuk masa yang akan datang.Dengan demikian penerapan TQMini sangat membantu institusi pendidikan dalam mengelola perubahan dan menyusun agenda program pendidikanuntuk memenuhi harapan pelanggannya. Sebagaimana dinyatakan oleh Sallisbahwa:"Total Quality Management is a philosophy and a methodology which assist institutions to manage change and set their own agendas for dealing with the plethora of new external pressures".(2002: 13).

Dengan demikian penerapan TQM dalam organisasi sekolah dilakukan sebagai upaya untuk memperbaiki mutu pendidikan di sekolah, sehingga sekolah mampu menciptakan keuntungan kompetitif lulusannya dengan mutu pendidikan yang tinggi. TQM merupakan hal yang sangat diperlukan karena saat ini tidak ada institusi pendidikan yang tidak berorientasi pada peningkatan mutu pendidikannya. Berkaitan dengan penerapan TQM, Fieldsmenyatakanbahwa penerapan TQM dalam bidang pendidikan dilakukan dalambentuk prinsip-prinsip (1994: 23-25). Bahkan penerapan prinsip-prinsip TQM akan menunjukkan hasil positif, sehingga sekolah mengadopsi TQMsebagai proses perbaikan dan pembangunan kembali pendidikan di sekolahnya (West-Burnham, 1998: 320).

Prinsip-prinsip dalam TQM ini ibaratnya sebagai suatu pilar yang memberi kekuatan dalam menggerakkan organisasi sekolah. Dengan pilar ini diharapkan dapat membantu organisasi sekolah dalam peningkatan proses pendidikannya.Schargel (1994: 6-7) menyebutkan beberapa fungsi dari penerapan prinsip-prinsip dalam TQM, yaitu: (1) memberikan peta arah suatu perubahan sekolah,(2) membantu kerjasama sebagai tim kerja sekolah, (3) menjadikan suatu program 
sekolah secara holistik, (4) meningkatkan partisipasi semua orang untuk terlibat dalam pengelolaan sekolah,(5) mengembangkan kerjasama dengan orang tua dan siswa dalam menetapkan standar mutu pendidikan sekolah,dan (6) menjadikan semua warga sekolah untuk bertindak proaktif. Dengan demikianprinsip-prinsip TQM ini sangat penting bagi organisasi sekolah karena menjadi dasar dalam penerapan TQM di sekolah tersebut.

Menurut Oakland (1989: 297) ada tiga prinsip dasar dalam peningkatan mutuorganisasi sekolah, yaitu: (1) memusatkan pada pelangganpendidikan di sekolah, (2) memahami prosespendidikan, dan (3) melibatkan banyak warga sekolah.Sedangkan Dale (2006: 32-34) menyatakan bahwa elemen kunci dalam melaksanakan TQM, yaitu: (1) komitmen dan kepemimpinan manajer senior, (2) perencanaan dan pengorganisasian,(3) penggunaan teknik dan alat manajemen mutu,(4) pendidikan dan pelatihan,(5) keterlibatan semua orang,(6) kerjasama tim,(7) pengukuran dan umpanbalik,dan (8) kerja bersama-sama.

Pengertian bahwa TQM sebagai sebuah filosofi tentang perbaikan secara terus menerus yang dapat memberikan seperangkat alat praktis kepada setiap institusi pendidikan dalam memenuhi kebutuhan, keinginan, dan harapan para pelanggannya, saat ini dan untuk masa yang akan datang. Dengan demikian penerapan TQM ini sangat membantu institusi pendidikan dalam mengelola perubahan dan menyusun agenda program pendidikanuntuk memenuhi harapan pelanggannya. Sebagaimana dinyatakan oleh Sallis bahwa:"Total Quality Management is a philosophy and a methodology which assist institutions to manage change and set their own agendas for dealing with the plethora of new external pressures".(2002: 13).Dengan demikian penerapan TQM dalam organisasi sekolah dilakukan sebagai upaya untuk memperbaiki mutu pendidikan di sekolah, sehingga sekolah mampu menciptakan keuntungan kompetitif lulusannya dengan mutu pendidikan yang tinggi. TQM merupakan hal yang sangat diperlukan karena saat ini tidak ada institusi pendidikan yang tidak berorientasi pada peningkatan mutu pendidikannya. Berkaitan dengan penerapan TQM, Fields menyatakan bahwa penerapan TQM dalam bidang pendidikan dilakukan dalambentuk prinsip-prinsip (1994: 23-25). Bahkan penerapan prinsipprinsip TQM akan menunjukkan hasil positif, sehingga sekolah mengadopsi TQM sebagai proses perbaikan dan pembangunan kembali pendidikan di sekolahnya (WestBurnham, 1998: 320).Prinsip-prinsip dalam TQM ini ibaratnya sebagai suatu pilar yang memberi kekuatan dalam menggerakkan organisasi sekolah.

Dengan pilar ini diharapkan dapat membantu organisasi sekolah dalam peningkatan proses pendidikannya.Schargel (1994: 6-7) menyebutkan beberapa fungsi dari penerapan prinsip-prinsip dalam TQM, yaitu: (1) memberikan peta arah suatu perubahan sekolah,(2) membantu kerjasama sebagai tim kerja sekolah, (3) menjadikan suatu program sekolah secara holistik, (4) meningkatkan partisipasi semua orang untuk terlibat dalam pengelolaan sekolah,(5) mengembangkan kerjasama dengan orang tua dan siswa dalam menetapkan standar mutu pendidikan sekolah,dan (6) menjadikan semua warga sekolah untuk bertindak proaktif. Dengan demikianprinsip-prinsip TQM ini sangat penting bagi organisasi sekolah karena menjadi dasar dalam penerapan TQM di sekolah tersebut.Menurut Oakland (1989: 297) ada tiga prinsip dasar dalam peningkatan mutuorganisasi sekolah, yaitu: (1) memusatkan pada pelanggan pendidikan di sekolah, (2) memahami prosespendidikan, dan (3) melibatkan banyak warga sekolah. 
Sedangkan Dale (2006: 32-34) menyatakan bahwa elemen kunci dalam melaksanakan TQM, yaitu: (1) komitmen dan kepemimpinan manajer senior, (2) perencanaan dan pengorganisasian,(3) penggunaan teknik dan alat manajemen mutu,(4) pendidikan dan pelatihan,(5) keterlibatan semua orang,(6) kerjasama tim,(7) pengukuran dan umpanbalik,dan (8) kerja bersama-sama.Prinsip-prinsip dalam TQM menunjukkan suatu pedoman bagaimana pengelolaan organisasi sekolah itu akan dilakukan, sehingga dinyatakan oleh Acaro bahwa prinsip-prinsip TQMdalam suatu organisasi sekolah itu mengandung, antara lain: (1) tujuan yang jelas dan tetap, (2) pembelajaran sistemik,(3) berfokus pada pelanggan,(4) kepemimpinan,(5) manajemen berdasarkan fakta,(6) perbaikan proses berkelanjutan,(7) manajemen partisipatif,(8) pengembangan sumber daya manusia,(9) bekerja secara tim,dan (10) komitmen untuk jangka panjang (1995: 25).

Dalam institusi pendidikan, menurut Sallis (2002: 7-11) ada beberapa prinsip yang harus diperhatikandalam penerapan TQM, yaitu:(1)perbaikan secara terus menerus,(2) menentukan standar penjaminan mutu,(3) perubahan kultur,(4) perubahan organisasi,dan (5) mempertahankan hubungan dengan pelanggan. Sedangkan Cokeley (2007: 20) menambahkan bahwa organisasipendidikan yang menerapkan TQM dibangun oleh empat pilar yaitu: (1) kepemimpinan mutu yang kuat,(2) perbaikan yang berkelanjutan atau terus menerus,(3) fokus pada pelanggan,dan (4) fokus pada proses atau sistem. Sedangkan masingmasing pilar itu mempunyai tujuan antara lain: (1) mendemonstrasikan komitmen dan terlibat aktif dalam menerapkan prinsipprinsip manajemen mutu terpadu,(2) melakukan perbaikan mutu secara terus menerus kepada siswa, staf dan komunitas sekolah,(3) meningkatkan kepuasan pelanggan pada pendidikan yang bermutu;
(4) menggunakan pendekatan sistem dan mengatur semua proses sebagai bagian dari sistem keseluruhan.

Amerika Serikat mulai menerapkan prinsip-prinsip TQM pada tahun 1990-an. Sekolah-sekolah di Amerika Serikat mulai mengimplementasikan teknik-teknik yang digunakan dalam TQM di industri pada proses pendidikan di sekolah. Ternyata prinsip-prinsip manajemen mutu ini sangat membantu dalam proses pendidikan di sekolah. Penerapan prinsip-prinsip TQM pada bidang pendidikan sudahbanyak dilakukan oleh para ahli.

Pemikiran yang digunakan dalam penerapan TQM ini untuk meningkatkan kinerja sekolah (Murgatroyd dan Mogan, 1993: 2).Sedangkan Sallis (2002: 75) mengatakan bahwa program TQM yang terpenting adalah untuk memberikan pengaruh terhadap budaya sekolah. Perubahan budaya sekolah ini membutuhkan waktu yang cukup lama, bahkan membutuhkan perubahan sikap dan metode. Perubahan budaya ini tidak hanya bicara tentang merubah perilaku, tetapi juga memerlukan perubahan dalam metode mengarahkan sebuah institusi. Perubahan metode tersebut ditandai dengan pemahaman bahwa orang menghasilkan mutu.

\section{c. Total Quality Management (TQM) di Sekolah Dasar}

Proses penyelenggaraan pendidikan tidak dapat dilepaskan dari profesionalisasi pengelola pendidikan dalam melaksanakan tugasnya. Pidarta (2000:286) mengatakan bahwa penyelenggara pendidikan adalah mereka yang menduduki jabatan struktural, seperti kepala sekolah, ketua jurusan, ketua, dan rektor. Pejabat struktural di kantorkantor dalam lingkungan pendidikan juga dapat disebut penyelenggara pendidikan, walaupun hanya menangani aturan dan kebijakan, sebab kedua hal ini mempengaruhi bahkan hal-hal tertentu menentukan pelaksanaan di sekolah. 
Penerapan Manajemen Mutu terpadu di sekolah tidak terlepas bagaimana upaya kepala sekolah mampu mengendalikan mutu pengelolaan sekolah tersebut secara terpadu. Pengendalian mutu terpadu merupakan suatu sistem yang paling efektif untuk mengintegrasikan usaha-usaha pengembangan kualitas, pemeliharaan kualitas, dan perbaikan kualitas dari berbagai level organisasi sehingga meningkatkan produktivitas (Hasibuan, 2000:219). Dari pernyataan tersebut tersirat bahwa seharusnyalah seorang Kepala sekolah harus dapat melaksanakan pengendalian mutu secara terpadu agar terjadi peningkatan hasil yang lebih baik dan efektif. Pertanyaannya adalah bagaimana menjalankan pengendalian mutu tersebut, Hasibuan (2000:220) mengatakan bahwa dasar utama menjalankannya adalah mentalitas, kecakapan, dan manajemen partisipatif dengan sikap mental yang mengutamakan kualitas kerja. Mentalitas adalah kesediaan bekerja sungguh-sungguh, jujur, dan bertanggung jawab melaksanakan pekerjaannya. Untuk menerapkan TQM di sekolah diperlukan syarat-syarat sebagai berikut:

1. Seluruh SDM ("perangkat sekolah") yang turut serta dalam proses kegiatan ("pengelolaan sekolah") harus mengerti dan menghayati arti TQM, mampu, bermental baik, dan bertanggung jawab sepenuhnya terhadap penyelesaian pekerjaannya.

2. TQM sebagai totalitas pengendalian terhadap mutu produk ("lulusan") secara bertahap dan merupakan rangkaian suatu proses diharuskan agar setiap kelompok kerja ("guru") bekerja benar dalam rangkaian terpadu dari gugus kendali mutu tersebut.

3. Seluruh mata rantai dalam subsistem harus mampu bekerja efisien dan efektif dengan didukung sikap mental positif dari setiap individu anggotanya. Sikap mental positif adalah kesediaan untuk bekerja produktif dalam spirit kerjasama yang kuat, untuk mencapai mutu kerja yang tinggi.

4. Sarana, prasarana, dan Lingkungan kerja harus mendukung pelaksanaan TQM. Setiap individu karyawan harus mengetahui dan berpartisipasi dalam mengerjakan pekerjaan secara benar, sehingga barang/jasa ("lulusan") yang dihasilkan bermutu tinggi.

Kendala pelaksanaan program TQM datang dari bawahan dan atasan, saya membatasi kendala hanya dari atasan yaitu kepala sekolah. We can't see a Good School without a Good Principle, kendala dari atasan ("kepala sekolah") menurut Hasibuan (2000:225) adalah (a) atasan tidak mendukung gagasan TQM; (b) sangat sibuk, tidak ada waktu; (c) kurangnya kewenangan yang dimiliki; (d) belum memahami secara jelas pengertian TQM, dan (e) atasan menganut sentralisasi wewenang. Sedangkan hambatan dari pihak guru biasanya tergantung bagaimana gaya kepemimpinan kepala sekolah, salah satu cara menggerakkan guru dan staf lainnya untuk berpartisipasi dalam menjalankan TQM adalah prinsip motivasi. Kepala sekolah harus mampu merangsang guru termotivasi untuk mengerjakan tugasnya. Uno (2007:71) mendifinisikan motivasi kerja sebagai salah satu faktor yang turut menentukan kinerja seseorang. Besar atau kecilnya pengaruh motivasi pada kinerja seseorang tergantung pada seberapa banyak intensitas motivasi yang diberikan. Jadi jika dikaitkan dengan motivasi kerja seorang guru dalam mengajar biasanya tercermin dalam berbagai kegiatan dan bahkan prestasi yang dicapai guru tersebut. Sedangkan motivasi kerja guru menurut Uno (2007) adalah suatu proses yang dilakukan untuk menggerakkan guru agar perilaku mereka dapat diarahkan pada upaya-upaya nyata untuk mencapai tujuan yang telah ditetapkan. 


\section{KESIMPULAN}

Mutu pendidikan adalah derajat keunggulan dalam pengelolaan pendidikan secara efektif dan efisien untuk melahirkan keunggulan akademis dan ekstrakurikuler pada peserta didik yang dinyatakan lulus untuk satu jenjang pendidikan atau menyelesaikan program pembelajaran tertentu. Pengelolaan pendidikan dengan menciptakan lingkungan belajar yang kondusif serta berkelanjutan merupakan komitmen dalam pemenuhan janji sebagai pemimpin pendidikan. Pendidikan merupakan proses berkelanjutan. Pembelajaran yang efektif dan bermakna harus bersentuhan langsung dengan kehidupan siswa dilingkungannya. TQM ini ibaratnya sebagai suatu pilar yang memberi kekuatan dalam menggerakkan organisasi sekolah.

Dengan pilar ini diharapkan dapat membantu organisasi sekolah dalam peningkatan proses pendidikannya. Penerapan Manajemen Mutu terpadu di sekolah tidak terlepas bagaimana upaya kepala sekolah mampu mengendalikan mutu pengelolaan sekolah tersebut secara terpadu. Pengendalian mutu terpadu merupakan suatu sistem yang paling efektif untuk mengintegrasikan usaha-usaha pengembangan kualitas, pemeliharaan kualitas, dan perbaikan kualitas dari berbagai level organisasi sehingga meningkatkan produktivitas.

Kendala pelaksanaan program TQM datang dari bawahan dan atasan, saya membatasi kendala hanya dari atasan yaitu kepala sekolah. We can't see a Good School without a Good Principle, kendala dari atasan ("kepala sekolah") menurut Hasibuan (2000:225) adalah (a) atasan tidak mendukung gagasan TQM; (b) sangat sibuk, tidak ada waktu; (c) kurangnya kewenangan yang dimiliki; (d) belum memahami secara jelas pengertian TQM, dan (e) atasan menganut sentralisasi wewenang. Penerapan suatu sistem manajemen selalu mengakibatkan terganggunya keseimbangan. Timbul dua pihak yang pro dan kontra, menerima TQM dan menolak TQM Penolakan TQM dikarenakan adanya perubahan dalam manajemen, yaitu menyangkut nilai-nilai yang sudah mapan.

Berkaitan dengan penerapan TQM, Fields (1994: 23-25) menyatakan bahwa penerapan TQM dalam bidang pendidikan dilakukan dalambentuk prinsip-prinsip. Bahkan penerapan prinsip-prinsip TQM akan menunjukkan hasil positif, sehingga sekolah mengadopsi TQM sebagai proses perbaikan dan pembangunan kembali pendidikan di sekolahnya (West-Burnham, 1998: 320).Prinsip-prinsip dalam TQM ini ibaratnya sebagai suatu pilar yang memberi kekuatan dalam menggerakkan organisasi sekolah.

\section{DAFTAR PUSTAKA}

Ahmad, Dzaujak. 1996. Petunjuk Peningkatan Mutu Pendidikan di Sekolah Dasar. Jakarta: Depdikbud.

Barrie Dale dan Heather Bunney. 1999. Total Quality Management Blueprint. Oxford: Blackwell.

Bestefe.1999. Total Quality Management in Education 3rdEdition. London: Kogan Page Ltd. Direktorat Pembinaan SMK. 2005.Kebijakan SMK. Jakarta: Depdiknas.

Cravens, David W. 1996. Strategic Marketing. Jakarta: Erlangga.Nasution, M. N. 2000. Manajemen Mutu Terpadu; Total Quality Management. Jakarta: Ghalia Indonesia.

Darmadji, A. 2008. Implementasi TQM sebagai upaya Peningkatan Mutu Pendidikan di MAN Model Yogyakarta. el-Tarbawi, No $2 \mathrm{Vol}$ 1.

Edward Sallis. 2002. Total Quality Management in Education Third Edition.London: Kogan Page Ltd. 
Franklin P. Schargel. 1994. Transforming Education Through Total Quality Management: Practitioner's Guide. New York: Eye on Education.

Jennifer A. Earnshaw. 1996. "The Application of Total Quality Management to a College of Further Education," The Management of Educational Change, a Case Study Approach, ed. Paul Oliver. England: Arena.

Jerome S. Acaro. 1995. Qualiy in Education: An Implementation Handbook. Delray Beach Florida: St. Lucie Press.

John Pike dan Richard Barnes. 1994. TQM In Action: A Practical Approach to Continuous

Performance Improvement. London: Chapman \& Hall.

John S. Oakland. 1989. Total Quality Management. Oxford, Heinemam Profesional Publishing.

Joseph C. Fields. 1994. Total Quality for schools, a Guide for Implementation. Wiscounsin: ASQC Quality Press.

Louis M. Savary. 1992. Creating Quality Schools. Virginia: American Association of School Administrators

Nawawi, Hadari. 2003. Manajemen Strategik Organisasi Non Profit Bidang Pemerintahan dengan Ilustrasi di Bidang Pendidikan. Yogyakarta: Gadjah Mada University Press

Agung, A., Agung, G., Dewi, P. Y. A., \& Dantes, K. R. (n.d.). The Organizational Commitment of Teachers at SMP Negeri in Sawan District, Buleleng Regency, Bali Province. 1st International Conference on Innovation in Education (ICoIE 2018). https://doi.org/https://doi.org/10.299 1/icoie-18.2019.55

Primayana, K. H. (2016). Manajemen Sumber Daya Manusia Dalam Peningkatan Mutu Pendidikan Di
Perguruan Tinggi. Jurnal Penjaminan Mutu. https://doi.org/10.25078/jpm.v1i2.45

Primayana, K. H. (2019). The Implementation Of School Management Based On The Values Of Local Wisdom Tri Hita Karana And Spiritual Intelligence On Teacher Organizational Commitments. Proceeding International Seminar (ICHECY), 154-159. Retrieved from http://jurnal.stahnmpukuturan.ac.id/i ndex.php/ichecy/article/view/134/12 7

Yulia, P., Dewi, A., \& Primayana, K. (2019). Effect of Learning Module with Setting Contextual Teaching and Learning to Increase the Understanding of Concepts. 1(1), 19-26.

https://doi.org/https://doi.org/10.317 63/ijele.v1i1.26

Sandra Cokeley, et al.2007. Transformation to Performancre Excellence. Wiscounsin: ASQ Quality Press.

Stephen Murgatroyd dan Colin Mogan. 1993. Total Quality Management and The School. Buckingham: Open University Press.

Syafaruddin. 2008. Efektivitas Kebijakan Pendidikan. Jakarta: Rineka Cipta.

Uno, Hamzah B. 2007. Model Pembelajaran Menciptakan Proses Belajar Mengajar yang Kreatif dan Efektif. Jakarta: Bumi Aksara.

Vincent Gaspersz. 2006. Total Quality Management (TQM) untuk Praktisi Bisnis dan Industri. Jakarta: Gramedia Pustaka Utama.

West-Burnham. 1998. Understanding Quality, dalam "The Principles and Practice of Educational Management". England: Pearson Education Ltd 